\title{
Forms and mobility of trace elements in soils of park areas from the city of Bydgoszcz, north Poland
}

\begin{abstract}
Increasing human activity affects urban ecosystem, including soils. The objective of the study were examine the content of lead, cadmium, copper, zinc, and manganese in soils of city parks and green areas from Bydgoszcz agglomeration, north Poland, estimate their forms and mobility, characterize distribution within soil profile, and estimate their origin - anthropogenic or natural. Three green areas from the older part of the city were selected for the study. Multistep sequential extraction method was conducted for the separation of seven metal fractions. It is concluded that soil studied were contaminated mainly by zinc and lead. These metals exist mainly in relatively non mobile forms i.e. associated with amorphous and crystalline iron oxides and with soil organic matter. The distribution within soil depth varied due to the elution process and variation of mixed soil material and additives.
\end{abstract}

Keywords: park soils, heavy metals, mobility

\section{INTRODUCTION}

Urban land differs in a number of aspects from the other environments. Soils in urban areas are highly modified and intensively managed. Anthropogenic disturbances involve soil profile changes, sealing, removal or addition of soil material and compaction (Poyat et al. 2007). The second type of changes arises from atmospheric deposition and input of contaminants in forms of solid particles (dusts rich in heavy metals), liquid or gaseous contaminations (acid rain, nitrogen and sulphur oxides) and other (Li et al. 2001, Shi et al. 2008). The pollution is related to metallic aerosols from industry as well as combustion of fossil fuels and the impact of traffic (Bilos et al. 2001). City green areas are usually treated with high doses of fertilizers and pest control chemicals. Such soils might be a source of human health hazard and can influence conditions of all living organisms, including plants. Soils in city parks and recreation areas have direct influence on health of inhabitants due to direct contact or as a suspended dust (Lee et al. 2006). Furthermore, the accumulation of metals in soils may be the source of ground water pollution and may cause the contamination of water resources used for consumption (Lerner 1996, Mohrlok, Schiedek 2007). The toxic effect of trace elements accumulated in soils and the risk of water pollution are related to form and mobility of metals.
Metals in soils are present in several different phases which differ in their solubility, mobility and bioavailability. It is necessary to quantify forms of metals since their geochemical transport and mobility largely depend on their forms and association with soil components. The investigations focused on $\mathrm{Pb}, \mathrm{Cd}$, $\mathrm{Cu}$ and $\mathrm{Zn}$ due to their prevalence in urban environment. These elements are called urban agglomeration contaminants (Deboudt et al. 2004). Furthermore, the content of manganese was analysed since this metal distribution in soil could be the indicator of the disturbance of soil material due to its properties and mainly natural origin (Mielke et al. 2002). The objectives of the study were to: (1) examine the content of lead, cadmium, copper, zinc and manganese in soils of city parks and green areas in Bydgoszcz agglomeration,(2) estimate their forms and mobility (3) characterize distribution with soil depth, and (4) estimate their origin (anthropogenic vs. natural).

\section{MATERIALS AND METHODS}

Bydgoszcz, a city with a population of 368.000 inhabitants, is impacted by numerous anthropogenic sources of metal emissions such as local industry, fossil fuel combustion plants and motor vehicle emissions. Three public green areas from the central part of Bydgoszcz city were selected for the study: Kazimierz Wielki Park, Botanical Garden and green area at Ber- 
nardyńska Street, in the close vicinity of roads with heavy traffic. Soils were sampled from 3 depths: 0-20, $40-60$ and $90-110 \mathrm{~cm}$. All sites are located in the inner, older parts of the city.

According to Polish Soil Classification (2011), studied soils were classified as Anthropogenic soils, mechanically transformed with artefacts, building debris and technique materials in profiles, increased content of heavy metals and modified $\mathrm{pH}$ (Urbizems chemically transformed).

Samples were air dried, and sieved through a $2 \mathrm{~mm}$ mesh sieve. Soil $\mathrm{pH}$ was measured in $\mathrm{H}_{2} \mathrm{O}$ and $1 \mathrm{M} \mathrm{KCl}$ solution using 1:2.5 w:v soil/solution ratio. Organic carbon was determined using Tyurin method by wet oxidation at $180^{\circ} \mathrm{C}$ with a mixture of potassium dichromate and sulfuric acid. The content of clay fraction $(<0.002 \mathrm{~mm})$ was measured according to BoycouseCassegrande method.

The concentrations of total metal contents in soils were determined after the digestion in a mixture of concentrated $\mathrm{HF}$ and $\mathrm{HClO}_{4}$ (Crock and Severson 1980). For the determination of the distribution of metals among physicochemical phases, selective sequential chemical extraction was used. Modified Miller et al. (1986) procedure was applied for the determination of metal fractions associated with soil components. The extraction was carried out progressively on an initial weight of $2.0 \mathrm{~g}$ of soil. The extractants and operationally defined chemical fractions of metals were as follow:

1. Fraction 1 (F1): exchangeable ions; soil extracted with $20 \mathrm{ml}$ of $0.5 \mathrm{M} \mathrm{Ca}\left(\mathrm{NO}_{3}\right)_{2}$ at $\mathrm{pH} 7.0$ for 2 hours with continuous agitation at room temperature;

2. Fraction 2 (F2): metals specifically adsorbed and bound to carbonate; residue from Step 1 was extracted with $0.44 \mathrm{M} \mathrm{CH}_{3} \mathrm{COOH}+0.1 \mathrm{M} \mathrm{Ca}\left(\mathrm{NO}_{3}\right)$ at room temperature for 4 hours;

3. Fraction 3 (F3):metals bound to Mn-oxides; the residue from Step 2 was extracted with $20 \mathrm{ml}$ of 0.1 $\mathrm{M} \mathrm{NH}_{2} \mathrm{OH} \cdot \mathrm{HCl}+0.01 \mathrm{M} \mathrm{HNO}_{3}$ for 6 hours;

4. Fraction $4(\mathrm{~F} 4)$ :metals bound to organic matter; the residue from Step 3 was extracted with $20 \mathrm{ml} 0.1$ $\mathrm{M} \mathrm{K}_{4} \mathrm{P}_{2} \mathrm{O}_{7}$;

5. Fraction 5 (F5):metals bound to amorphous $\mathrm{Fe}$ oxides; extracted with $0.175 \mathrm{M}\left(\mathrm{NH}_{4}\right)_{2} \mathrm{C}_{2} \mathrm{O}_{4}+0.1 \mathrm{M}$ $\mathrm{H}_{2} \mathrm{C}_{2} \mathrm{O}_{4}$ in darkness;

6. Fraction $6(\mathrm{~F} 6)$ :metals bound to crystalline $\mathrm{Fe}$ oxides, extracted with $20 \mathrm{ml} 0.175 \mathrm{M}\left(\mathrm{NH}_{4}\right)_{2} \mathrm{C}_{2} \mathrm{O}_{4}+$ $0.1 \mathrm{M} \mathrm{H}_{2} \mathrm{C}_{2} \mathrm{O}_{4}+$ ascorbic acid.

Residual fraction of metal (fraction 7 - F7) was calculated as the difference from the total content and the sum of extractable fractions.

The concentration of $\mathrm{Pb}, \mathrm{Cd}, \mathrm{Cu}$ and $\mathrm{Zn}$ in solutions was determined by flame AAS technique, using SP
2900 spectrometer. The accuracy and precision of the analyses were assessed by the analyses of certificate reference material (Reference soil sample SO - 4. Canada Centre for Mineral and Energy Technology). All extractions were done on duplicate samples from the same site, and the average results were used for further analysis. Correlation coefficients between investigated metals and soil properties were calculated based on the Statistica 12 software.

\section{RESULTS AND DISCUSSION}

The soils analysed differed in organic carbon content which varied in the ranges $11.8-45.6 \mathrm{~g} \cdot \mathrm{kg}^{-1}$ and $0.5-13.4$ $\mathrm{g} \cdot \mathrm{kg}^{-1}$ in the surface and in the deeper layers, respectively (Table 1). Other authors (Oktaba et al. 2014) also reported that urban soils contain high amounts of organic matter. Contents of clay fraction were in the range $4-68 \%$ (Table 1). The amount of clay fraction indicate significant discontinuities in 3 pits from Botanical garden (sites D, E and F). It is confirmed by the differentiation of $\mathrm{Mn}$ content in these sites. This might be caused by the replacement of natural soil by material coming from other places. The levelling of the terrain and the creation of lawns is often accompanied by the partial removal of the original soil material (natural soil) and formation of specific urban soil.

Cation exchange capacity, related to the soils composition is rather low ranging from 16.0 to 57.2 $\mathrm{mmol} \cdot \mathrm{kg}^{-1}$ (Table 1).

Total metal concentrations in soil samples are shown in Table 2. Of all metals studied, cadmium has the lowest concentrations and the amounts $(0.3-$ $1.2 \mathrm{mg} \cdot \mathrm{kg}^{-1}$ ) do not differ much from one site to another. These results indicate that $\mathrm{Cd}$ present in soils must be mainly of lithogenic origin and is not much contributed by anthropogenic activities. For other metals, elevated metal concentrations were observed. Contents of the studied elements were in the range: 5.4-148.9 $\mathrm{mg} \cdot \mathrm{kg}^{-1}$ for $\mathrm{Pb}, 3.6-33.4 \mathrm{mg} \cdot \mathrm{kg}^{-1}$ for $\mathrm{Cu}, 10.4-182.1$ $\mathrm{mg} \cdot \mathrm{kg}^{-1}$ for $\mathrm{Zn}$, and $18.5-468.0 \mathrm{mg} \cdot \mathrm{kg}^{-1}$ for Mn. Other authors studying soils in city areas all over the world reported high concentrations of heavy metals, particularly lead, copper and zinc (Hursthouse et al. 2004, Madrid et al. 2004, Chen et al. 2005, Shi et al. 2008). With $\mathrm{Pb}$ and $\mathrm{Zn}$ concentrations in the range of 5.4$148.9 \mathrm{mg} \cdot \mathrm{kg}^{-1}$ and $10.4-182.1 \mathrm{mg} \cdot \mathrm{kg}^{-1}$, respectively, the studied soils are only moderately contaminated compared to other soils affected by urban activities (Madrid et al. 2006).

One of the main sources of metals in big cities is the dust fall of different origin. Detailed study of the street dusts showed that particles contain metals such 
TABLE 1. Selected soil properties

\begin{tabular}{|c|c|c|c|c|c|c|}
\hline $\begin{array}{l}\text { No. } \\
\text { of } \\
\text { sample }\end{array}$ & $\begin{array}{l}\text { Depth } \\
\text { (cm) }\end{array}$ & $\mathrm{H}_{2} \mathrm{O}$ & $1 \mathrm{M} \mathrm{KCl}$ & $\left(\mathrm{g} \cdot \mathrm{kg}^{-1}\right)$ & $\begin{array}{l}\text { Clay } \\
(\%)\end{array}$ & $\left(\mathrm{mmol} \cdot \mathrm{kg}^{-1}\right)$ \\
\hline \multicolumn{7}{|c|}{ Kazimierz Wielki Park } \\
\hline \multicolumn{7}{|l|}{ Site A } \\
\hline 1 & $0-20$ & 7.0 & 6.8 & 45.6 & 9 & 53.7 \\
\hline 2 & $40-60$ & 7.8 & 6.5 & 12.6 & 9 & 52.6 \\
\hline 3 & $90-110$ & 7.0 & 6.9 & n.d. & 9 & 33.6 \\
\hline Site B & & & & & & 53.8 \\
\hline 4 & $0-20$ & 7.2 & 7.2 & 12.0 & 9 & \\
\hline 5 & $40-60$ & 7.7 & 7.5 & 1.1 & 6 & 49.0 \\
\hline 6 & $90-110$ & 7.9 & 7.4 & n.d. & 4 & 9.82 \\
\hline \multicolumn{7}{|l|}{ Site C } \\
\hline 7 & $0-20$ & 6.9 & 6.8 & 19.1 & 9 & 36.9 \\
\hline 8 & $40-60$ & 7.3 & 7.1 & 6.9 & 6 & 23.6 \\
\hline 9 & $90-110$ & 7.1 & 7.0 & n.d. & 4 & 16.0 \\
\hline \multicolumn{7}{|c|}{ Botanical Garden } \\
\hline \multicolumn{7}{|c|}{ Site D } \\
\hline 10 & $0-20$ & 7.0 & 7.0 & 17.2 & 12 & 26.3 \\
\hline 11 & $40-60$ & 6.9 & 6.7 & 1.2 & 5 & 7.8 \\
\hline 12 & $90-110$ & 7.1 & 6.3 & n.d. & 62 & 20.9 \\
\hline \multicolumn{7}{|c|}{ Site E } \\
\hline 13 & $0-20$ & 7.0 & 6.9 & 27.1 & 16 & 48.9 \\
\hline 14 & $40-60$ & 7.2 & 6.8 & 6.3 & 16 & 29.3 \\
\hline 15 & $90-110$ & 7.5 & 7.0 & n.d. & 68 & 33.6 \\
\hline \multicolumn{7}{|l|}{ Site F } \\
\hline 16 & $0-20$ & 7.3 & 6.9 & 11.8 & 16 & 55.2 \\
\hline 17 & $40-60$ & 7.3 & 6.9 & 0.5 & 56 & 26.9 \\
\hline 18 & $90-110$ & 7.5 & 6.9 & n.d. & 60 & 52.9 \\
\hline \multicolumn{7}{|c|}{ Site G } \\
\hline 19 & $0-20$ & 7.3 & 7.2 & 18.3 & 10 & 56.2 \\
\hline 20 & $40-60$ & 7.7 & 7.3 & 1.4 & 11 & 56.8 \\
\hline 21 & $90-110$ & 7.7 & 7.4 & n.d. & 11 & 57.2 \\
\hline \multicolumn{7}{|c|}{ Green Area at Bernardyńska Street } \\
\hline \multicolumn{7}{|c|}{ Site $\mathrm{H}$} \\
\hline 22 & $0-20$ & 7.3 & 7.2 & 25.8 & 11 & 12.7 \\
\hline 23 & $40-60$ & 7.7 & 7.3 & 13.4 & 11 & 54.7 \\
\hline 24 & $90-110$ & 7.6 & 7.3 & n.d. & 13 & 52.3 \\
\hline \multicolumn{7}{|l|}{ Site I } \\
\hline 25 & $0-20$ & 7.2 & 6.9 & 30.1 & 12 & 51.7 \\
\hline 26 & $40-60$ & 7.7 & 7.5 & 11.0 & 12 & 56.7 \\
\hline 27 & $90-110$ & 7.6 & 7.4 & n.d. & 11 & 42.8 \\
\hline
\end{tabular}

n.d. - not determined.

as: zinc, copper and lead in relatively labile forms (Kalembkiewicz et al. 2014).

According to the results of chemical analyses, concentrations of metals such as $\mathrm{Pb}, \mathrm{Cd}, \mathrm{Zn}$ and $\mathrm{Cu}$ in most of samples do not exceed acceptable limits of the abundance in the soils (Regulation of the Minister of the Environment, 2002). Only in two samples (21 and 26) concentration of lead slightly exceeded the limit.

The results of the study show that higher $\mathrm{Pb}, \mathrm{Cu}$ and $\mathrm{Zn}$ concentrations occur mainly in top soils. In all the soil samples collected from $0-20 \mathrm{~cm}, 40-60$ $\mathrm{cm}$ and $90-110 \mathrm{~cm}$ depths from 9 selected sites, total contents of $\mathrm{Pb}, \mathrm{Cu}$ and $\mathrm{Zn}$ generally decrease with
TABLE 2. Total content of metals in soils

\begin{tabular}{|c|c|c|c|c|c|c|}
\hline \multirow{2}{*}{$\begin{array}{l}\text { No. } \\
\text { of } \\
\text { sample }\end{array}$} & \multirow{2}{*}{$\begin{array}{l}\text { Depth } \\
\text { (cm) }\end{array}$} & $\mathrm{Pb}$ & $\mathrm{Cd}$ & $\mathrm{Cu}$ & $\mathrm{Zn}$ & \multirow[t]{2}{*}{$\mathrm{Mn}$} \\
\hline & & \multicolumn{4}{|c|}{$\left(\mathrm{mg} \cdot \mathrm{kg}^{-1}\right)$} & \\
\hline \multicolumn{7}{|c|}{ Kazimierz Wielki Park } \\
\hline \multicolumn{7}{|c|}{ Site A } \\
\hline 1 & $0-20$ & 62.3 & 1.2 & 23.2 & 182.1 & 260.9 \\
\hline 2 & $40-60$ & 48.3 & 0.9 & 21.2 & 49.3 & 259.7 \\
\hline 3 & $90-110$ & 41.3 & b.d. & 69.0 & 60.0 & 257.4 \\
\hline \multicolumn{7}{|l|}{ Site B } \\
\hline 4 & $0-20$ & 45.9 & b.d. & 17.9 & 81.1 & 152.2 \\
\hline 5 & $40-60$ & 11.8 & b.d. & 5.0 & 18.1 & 31.2 \\
\hline 6 & $90-110$ & 5.4 & b.d & 3.6 & 10.4 & 20.4 \\
\hline \multicolumn{7}{|l|}{ Site C } \\
\hline 7 & $0-20$ & 38.4 & b.d & 15.2 & 87.3 & 261.4 \\
\hline 8 & $40-60$ & 20.7 & b.d & 8.6 & 26.5 & 268.4 \\
\hline 9 & $90-110$ & 18.6 & b.d & 9.0 & 25.6 & 394.8 \\
\hline \multicolumn{7}{|c|}{ Botanical Garden } \\
\hline \multicolumn{7}{|c|}{ Site D } \\
\hline 10 & $0-20$ & 37.6 & b.d. & 13.4 & 72.0 & 183.1 \\
\hline 11 & $40-60$ & 5.7 & 1.1 & 3.7 & 11.2 & 20.9 \\
\hline 12 & $90-110$ & 10.6 & 0.3 & 12.4 & 31.6 & 18.5 \\
\hline \multicolumn{7}{|l|}{ Site E } \\
\hline 13 & $0-20$ & 37.5 & 0.2 & 24.7 & 98.7 & 192.0 \\
\hline 14 & $40-60$ & 26.2 & 0.6 & 16.5 & 49.4 & 139.7 \\
\hline 15 & $90-110$ & 15.8 & 0.3 & 31.6 & 55.4 & 162.6 \\
\hline \multicolumn{7}{|l|}{ Site F } \\
\hline 16 & $0-20$ & 30.3 & 0.3 & 16.9 & 63.1 & 201.5 \\
\hline 17 & $40-60$ & 12.3 & 0.0 & 27.0 & 40.0 & 133.4 \\
\hline 18 & $90-110$ & 11.5 & 0.3 & 29.0 & 40.2 & 42.4 \\
\hline \multicolumn{7}{|c|}{ Site G } \\
\hline 19 & $0-20$ & 22.8 & 0.2 & 13.4 & 69.2 & 206.7 \\
\hline 20 & $40-60$ & 47.7 & 0.7 & 21.8 & 79.3 & 198.9 \\
\hline 21 & $90-110$ & 111.3 & 0.3 & 66.6 & 137.5 & 468.0 \\
\hline \multicolumn{7}{|c|}{ Green Area at Bernardyńska Street } \\
\hline \multicolumn{7}{|c|}{ Site $\mathrm{H}$} \\
\hline 22 & $0-20$ & 82.8 & 0.7 & 32.9 & 138.0 & 185.7 \\
\hline 23 & $40-60$ & 45.1 & 0.3 & 33.0 & 61.4 & 296.0 \\
\hline 24 & $90-110$ & 39.2 & 0.3 & 20.6 & 50.8 & 172.5 \\
\hline \multicolumn{7}{|l|}{ Site I } \\
\hline 25 & $0-20$ & 81.6 & 0.8 & 33.4 & 119.5 & 249.6 \\
\hline 26 & $40-60$ & 148.9 & 0.0 & 24.6 & 29.5 & 146.3 \\
\hline 27 & $90-110$ & 72.3 & 0.0 & 22.3 & 37.0 & 101.0 \\
\hline
\end{tabular}

b.d. - below detection limit.

depth. The trend was particularly steep for zinc. For one site $(G)$ the highest concentration of metals were detected in the deepest layer. Such metals distribution may indicate soil disturbance and different origin of soil material in this site. Numerous changes like excavation, water pipes installation and renovation lead to the disturbance of soil material (Mielke et al. 2002). Total manganese content as the indicator of soil uniformity within the site suggests different origin of materials in the sites: B, D, F, and I.

The sequential extraction method allowed to explain the binding capacities of soil components and forms of metals in studied soils. Non residual metal 
TABLE 3. Lead fractions in soils

\begin{tabular}{|c|c|c|c|c|c|c|c|}
\hline \multirow{2}{*}{$\begin{array}{l}\text { No. } \\
\text { of } \\
\text { sample }\end{array}$} & $\mathrm{F} 1$ & $\mathrm{~F} 2$ & $\mathrm{~F} 3$ & $\mathrm{~F} 4$ & F5 & F6 & F7 \\
\hline & \multicolumn{7}{|c|}{$\left(\mathrm{mg} \cdot \mathrm{kg}^{-1}\right)$} \\
\hline \multicolumn{8}{|c|}{ Kazimierz Wielki Park } \\
\hline \multicolumn{8}{|c|}{ Site A } \\
\hline 1 & $<0.01$ & b.d & 0.2 & 36.3 & 3.0 & 3.2 & 19.6 \\
\hline 2 & b.d & b.d & 0.5 & 28.3 & 1.9 & 3.0 & 14.6 \\
\hline 3 & b.d & b.d & 0.5 & 14.8 & 0.8 & 3.0 & 22.2 \\
\hline \multicolumn{8}{|c|}{ Site B } \\
\hline 4 & b.d & b.d & 0.6 & 25.9 & 3.3 & 4.1 & 12.0 \\
\hline 5 & b.d & b.d & 1.7 & 1.4 & b.d & 2.9 & 5.8 \\
\hline 6 & b.d & b.d & 0.3 & b.d & b.d & 2.9 & 2.2 \\
\hline \multicolumn{8}{|c|}{ Site C } \\
\hline 7 & b.d & 0.5 & 3.4 & 19.0 & 3.0 & 4.4 & 8.1 \\
\hline 8 & b.d & b.d & 4.3 & 5.0 & 0.6 & 3.2 & 7.6 \\
\hline 9 & b.d & b.d & 3.2 & 6.7 & 1.4 & 3.7 & 3.6 \\
\hline \multicolumn{8}{|c|}{ Botanical Garden } \\
\hline \multicolumn{8}{|c|}{ Site D } \\
\hline 10 & b.d & b.d & 2.3 & 13.4 & 2.0 & 3.7 & 16.2 \\
\hline 11 & b.d & b.d & b.d & b.d & b.d & 3.0 & 2.7 \\
\hline 12 & b.d & b.d & 0.3 & 0.6 & b.d & 2.5 & 7.2 \\
\hline \multicolumn{8}{|c|}{ Site E } \\
\hline 13 & b.d & b.d & b.d & 19.4 & 2.5 & 4.0 & 11.6 \\
\hline 14 & b.d & b.d & 1.4 & 8.9 & b.d & 3.9 & 1.2 \\
\hline 15 & b.d & b.d & b.d & 1.3 & b.d & 2.8 & 11.7 \\
\hline \multicolumn{8}{|c|}{ Site F } \\
\hline 16 & b.d & b.d & b.d & 14.1 & 3.6 & 4.2 & 8.4 \\
\hline 17 & b.d & b.d & 0.0 & 2.4 & 0.1 & 2.9 & 6.9 \\
\hline 18 & b.d & b.d & b.d & 2.0 & b.d & 3.1 & 6.4 \\
\hline \multicolumn{8}{|c|}{ Site G } \\
\hline 19 & b.d & b.d & b.d & 11.8 & 1.8 & 3.6 & 5.6 \\
\hline 20 & b.d & 0.6 & b.d & 27.7 & 3.2 & 4.3 & 11.9 \\
\hline 21 & b.d & 1.4 & b.d & 54.8 & 5.4 & 8.4 & 41.3 \\
\hline \multicolumn{8}{|c|}{ Green Area at Bernardyńska Street } \\
\hline \multicolumn{8}{|l|}{ Site H } \\
\hline 22 & b.d & 1.0 & 1.9 & 38.4 & 9.0 & 7.1 & 25.4 \\
\hline 23 & b.d & 0.0 & 1.0 & 22.9 & 4.0 & 4.4 & 12.8 \\
\hline 24 & b.d & b.d & 0.4 & 25.5 & 4.0 & 4.7 & 4.6 \\
\hline \multicolumn{8}{|l|}{ Site I } \\
\hline 25 & b.d & 0.3 & b.d & 50.3 & 7.2 & 6.5 & 17.3 \\
\hline 26 & b.d & 5.9 & 15.4 & 68.9 & 9.1 & 7.1 & 42.5 \\
\hline 27 & b.d & 2.7 & 18.0 & 46.7 & 6.0 & 4.9 & 6.0 \\
\hline
\end{tabular}

b.d. - below detection limit.

phases are most critical from toxicity perspective but also nutrition, since these are most likely to be available. The results indicate that the amounts of easily available metals are low, except for zinc which occurs in labile forms: exchangeable (F1) and acid soluble (F2) fractions - on average 2 and $17 \%$ respectively (Fig. 1).

Lead is mainly associated with soil organic matter (F4 up to $65.1 \%$ ) similarly like $\mathrm{Cu}$ (F4 up to $55.6 \%$ ). Moreover, lead is strongly retained on iron oxides and hydrooxides (F5 and F6) and the amount of this element adsorbed by these components is larger by an order of magnitude compared to the amount associated with manganese oxides (F3). Soil organic matter plays very significant role in binding of lead, copper and zinc (F4). After the removal of organic
TABLE 4. Copper fractions in soils

\begin{tabular}{|c|c|c|c|c|c|c|c|}
\hline \multirow{2}{*}{\multicolumn{8}{|c|}{$\begin{array}{l}\text { No. } \\
\text { of } \\
\text { sample }\end{array}$}} \\
\hline & & & & & & & \\
\hline \multicolumn{8}{|c|}{ Kazimierz Wielki Park } \\
\hline \multicolumn{8}{|c|}{ Site A } \\
\hline 1 & 0.8 & 0.1 & b.d. & 6.4 & 12.9 & 2.1 & 0.9 \\
\hline 2 & 0.6 & b.d. & 0.3 & 9.5 & 7.9 & 1.3 & 1.6 \\
\hline 3 & 0.5 & 1.4 & 1.4 & 19.5 & 18.3 & 3.3 & 24.6 \\
\hline \multicolumn{8}{|c|}{ Site B } \\
\hline 4 & 0.8 & b.d. & b.d. & 5.5 & 8.8 & 1.9 & 0.9 \\
\hline 5 & 0.7 & 0.1 & b.d. & 2.0 & 2.1 & 0.0 & 0.1 \\
\hline 6 & 0.7 & b.d. & b.d. & 2.0 & 0.7 & 0.0 & 0.2 \\
\hline \multicolumn{8}{|c|}{ Site C } \\
\hline 7 & 0.9 & 0.5 & 0.4 & 6.2 & 4.9 & 2.0 & 0.3 \\
\hline 8 & 0.8 & b.d. & 0.4 & 3.7 & 1.7 & 1.0 & 1.0 \\
\hline 9 & 1.1 & 0.0 & 0.3 & 4.4 & 1.7 & 0.6 & 0.9 \\
\hline \multicolumn{8}{|c|}{ Botanical Garden } \\
\hline \multicolumn{8}{|c|}{ Site D } \\
\hline 10 & 0.9 & 0.1 & 0.5 & 5.4 & 4.7 & 1.4 & 0.4 \\
\hline 11 & 0.9 & b.d. & 0.4 & 1.4 & 0.5 & 0.0 & 0.5 \\
\hline 12 & 1.1 & 0.5 & 0.5 & 1.3 & 5.2 & 5.6 & 1.8 \\
\hline \multicolumn{8}{|c|}{ Site E } \\
\hline 13 & 1.3 & 0.3 & 0.3 & 6.0 & 10.3 & 2.0 & 4.5 \\
\hline 14 & 1.3 & 0.2 & 0.9 & 5.3 & 4.1 & 1.2 & 3.5 \\
\hline 15 & 1.2 & b.d. & 0.4 & 2.5 & 1.5 & 4.6 & 21.4 \\
\hline \multicolumn{8}{|c|}{ Site F } \\
\hline 16 & 1.2 & 0.2 & b.d. & 1.1 & 5.9 & 2.6 & 5.9 \\
\hline 17 & 1.2 & 0.5 & 0.7 & 0.2 & 3.1 & 4.7 & 16.6 \\
\hline 18 & 1.1 & 0.4 & 0.5 & 2.7 & 3.0 & 4.4 & 16.9 \\
\hline \multicolumn{8}{|c|}{ Site G } \\
\hline 19 & 1.1 & 0.4 & 0.5 & 2.9 & 4.8 & 1.0 & 2.7 \\
\hline 20 & 1.1 & 0.4 & 0.2 & 5.1 & 4.7 & 1.9 & 8.4 \\
\hline 21 & 0.8 & 0.4 & 0.5 & 19.0 & 15.2 & 2.9 & 27.8 \\
\hline \multicolumn{8}{|c|}{ Green Area at Bernardyńska Street } \\
\hline \multicolumn{8}{|c|}{ Site $\mathrm{H}$} \\
\hline 22 & 1.7 & 0.8 & 1.1 & 9.3 & 11.7 & 3.8 & 4.5 \\
\hline 23 & 1.4 & 1.4 & 1.2 & 11.8 & 8.6 & 2.1 & 6.5 \\
\hline 24 & 1.2 & 0.6 & 0.8 & 8.0 & 5.9 & 2.4 & 1.7 \\
\hline \multicolumn{8}{|c|}{ Site I } \\
\hline 25 & 1.6 & 0.8 & 0.7 & 9.9 & 13.5 & 3.0 & 3.9 \\
\hline 26 & 1.4 & 4.1 & 3.7 & 5.9 & 5.7 & 2.1 & 1.7 \\
\hline 27 & 1.4 & 2.0 & 3.4 & 9.1 & 4.1 & 2.0 & 0.3 \\
\hline
\end{tabular}

matter the capacity of soil to retain metals decreases abruptly (Ladonin and Karpukhin 2008). Metals specifically adsorbed and bound to carbonates (F2) are not significant and for the majority of samples are below the detection limit. In our study we found that there is significant statistical correlation between the total $\mathrm{Zn}$ content and Corg $(0.752 ; \mathrm{p}<0.05)$ and significant correlation between $\mathrm{Zn}$ in $\mathrm{F} 4$ and Corg $(0.718 ; \mathrm{p}<0.05)$ as well as between $\mathrm{Pb}$ in $\mathrm{F} 4$ and Corg $(0.383 ; p<0.05)$. Moreover, copper and zinc are associated with amorphous iron oxides (F5) and crystalline iron oxides (F6).

The relative bioavailability (based on F1 and F2) decreases in the order: $\mathrm{Zn}>\mathrm{Pb}>\mathrm{Cu}$. No accumulation of cadmium was observed in studied park soils. 
TABLE 5. Zinc fractions in soils

\begin{tabular}{|c|c|c|c|c|c|c|c|}
\hline \multirow{2}{*}{$\begin{array}{l}\text { No. } \\
\text { of } \\
\text { sample }\end{array}$} & $\mathrm{F} 1$ & $\mathrm{~F} 2$ & $\mathrm{~F} 3$ & $\mathrm{~F} 4$ & F5 & F6 & F7 \\
\hline & \multicolumn{7}{|c|}{$\overline{\left(\mathrm{mg} \cdot \mathrm{kg}^{-1}\right)}$} \\
\hline \multicolumn{8}{|c|}{ Kazimierz Wielki Park } \\
\hline \multicolumn{8}{|c|}{ Site A } \\
\hline 1 & 3.1 & 28.7 & 18.6 & 32.6 & 19.4 & 25.7 & 54.0 \\
\hline 2 & b.d. & 4.2 & 5.0 & 7.7 & 4.0 & 8.7 & 19.7 \\
\hline 3 & 0.9 & 15.8 & 7.3 & 7.1 & 1.8 & 5.0 & 22.1 \\
\hline \multicolumn{8}{|c|}{ Site B } \\
\hline 4 & 0.7 & 18.6 & 12.2 & 14.0 & 6.6 & 11.9 & 17.1 \\
\hline 5 & b.d. & 6.2 & 1.8 & 5.7 & 0.9 & 2.1 & 1.4 \\
\hline 6 & 0.4 & 1.2 & b.d. & 3.9 & 0.1 & 1.0 & 3.8 \\
\hline \multicolumn{8}{|c|}{ Site $\mathrm{C}$} \\
\hline 7 & 6.5 & 27.7 & 12.3 & 10.4 & 6.1 & 10.3 & 1.4 \\
\hline 8 & 0.4 & 3.6 & 1.6 & 4.9 & 1.2 & 4.6 & 10.2 \\
\hline 9 & 0.3 & 2.9 & 1.1 & 4.7 & 1.2 & 3.8 & 11.6 \\
\hline \multicolumn{8}{|c|}{ Botanical Garden } \\
\hline \multicolumn{8}{|c|}{ Site D } \\
\hline 10 & 2.0 & 19.1 & 7.6 & 10.5 & 4.8 & 9.6 & 18.4 \\
\hline 11 & 0.6 & 0.1 & b.d. & 4.0 & 1.1 & 0.4 & 5.0 \\
\hline 12 & 0.3 & b.d. & b.d. & 4.6 & 1.6 & 1.0 & 24.1 \\
\hline \multicolumn{8}{|c|}{ Site E } \\
\hline 13 & 2.2 & 11.8 & 8.8 & 18.6 & 9.8 & 13.9 & 33.6 \\
\hline 14 & 0.6 & 5.4 & 3.8 & 9.5 & 3.6 & 6.1 & 20.4 \\
\hline 15 & 0.2 & b.d. & b.d. & 6.2 & 1.5 & 1.5 & 46.0 \\
\hline \multicolumn{8}{|c|}{ Site F } \\
\hline 16 & 1.4 & 5.7 & 3.9 & 14.0 & 7.7 & 11.8 & 18.6 \\
\hline 17 & 0.5 & 0.6 & b.d. & 6.0 & 1.1 & 0.7 & 31.1 \\
\hline & 0.6 & b.d. & b.d. & 5.6 & 1.0 & 0.3 & 32.7 \\
\hline \multicolumn{8}{|c|}{ Site $G$} \\
\hline 19 & 1.8 & 12.9 & 7.2 & 19.3 & 8.5 & 9.5 & 10.0 \\
\hline 20 & 1.4 & 13.7 & 7.3 & 15.5 & 7.8 & 12.5 & 21.1 \\
\hline 21 & 1.4 & 20.6 & 8.0 & 27.0 & 19.8 & 12.1 & 48.6 \\
\hline \multicolumn{8}{|c|}{ Green Area at Bernardyńska Street } \\
\hline \multicolumn{8}{|c|}{ Site $\mathrm{H}$} \\
\hline 22 & 3.7 & 37.1 & 18.3 & 22.3 & 19.6 & 13.7 & 23.3 \\
\hline 23 & 1.1 & 10.7 & 6.6 & 13.2 & 8.0 & 8.1 & 13.7 \\
\hline 24 & 1.0 & 9.8 & 7.4 & 13.2 & 6.3 & 6.3 & 6.8 \\
\hline \multicolumn{8}{|c|}{ Site I } \\
\hline 25 & 4.3 & 26.8 & 7.2 & 22.6 & 15.0 & 15.9 & 27.7 \\
\hline 26 & 1.1 & 7.2 & 3.5 & 8.2 & 3.6 & 3.9 & 2.0 \\
\hline 27 & 1.9 & 11.0 & 3.4 & 10.9 & 3.4 & 3.3 & 3.1 \\
\hline
\end{tabular}

b.d. - below detection limit.

\section{CONCLUSIONS}

Based on the results obtained it was concluded that currently soils in studied city parks in Bydgoszcz are not heavily contaminated with lead, copper and zinc. Generally, the amounts of metals are elevated but do not exceed acceptable levels (Regulation of the Minister of the Environment, 2002). Cadmium content is close to the geochemical background.

Chemical sequential analysis showed that metals occur in different, mostly low bioavailable fractions, except for zinc which mainly forms labile fractions: exchangeable, specifically adsorbed and associated with organic matter.
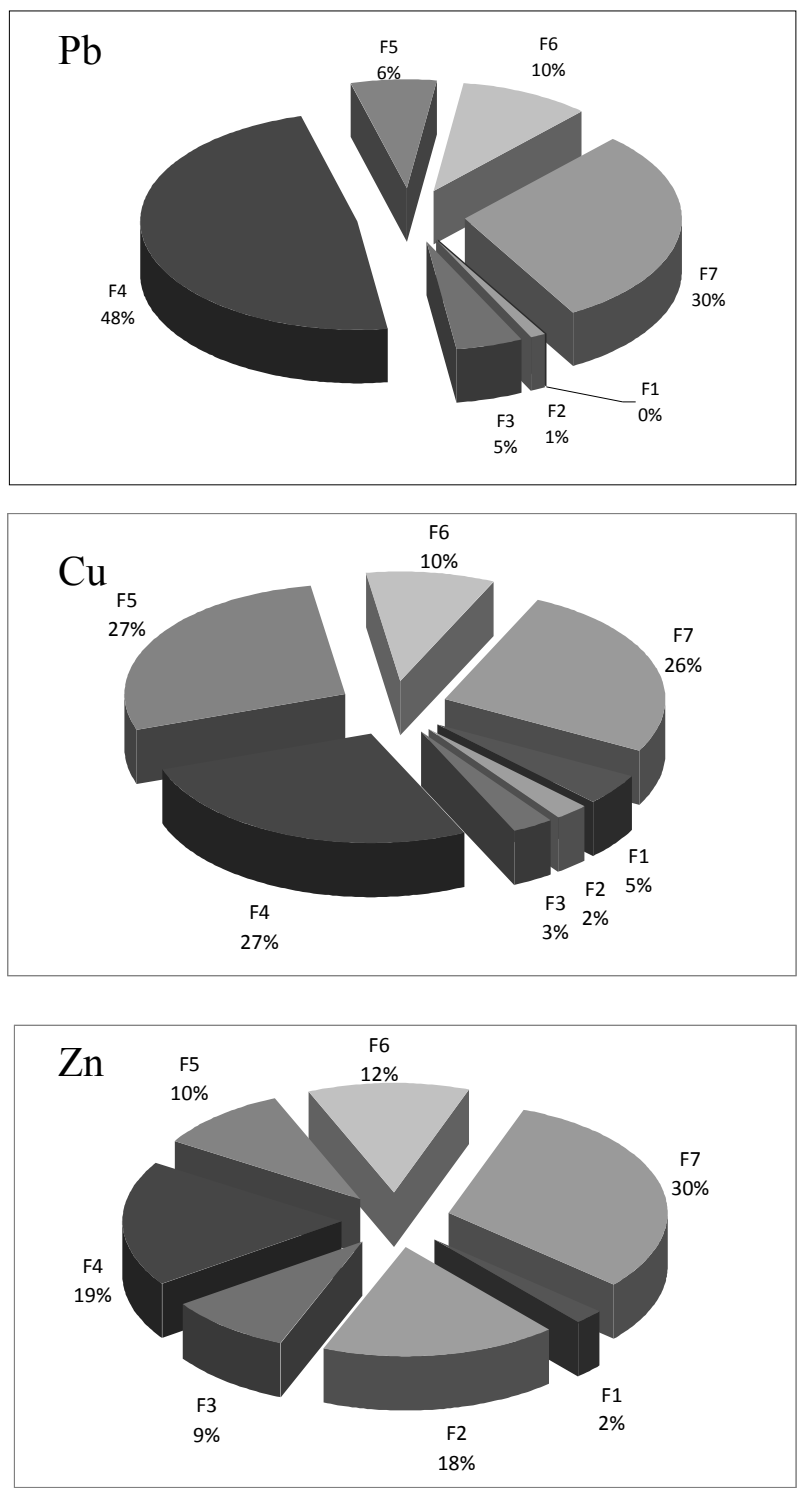

FIGURE 1. The mean percentage of analysed fractions in total content of the metals

However, it should be stressed that studied soils are vulnerable to contamination due to their texture and should be constantly monitored. Monitoring is recommended also because metal contents in the urban soils tend to increase.

\section{REFERENCES}

Bilos C., Colombo J.C., Skorupka N.C., Presa M.J.P., 2001. Source, distribution and variability of air borne trace metals in La Plata City area, Argentina. Environmental Pollution 111: 149-158.

Chen T.B., Zheng M., Lei Z.C., Huang H.T., Wu H., Chen K.K., Fan K., Yu X., Wu Q.Z., 2005. Assessment of heavy metal pollution in surface soils of urban parks in Beijing, China. Chemosphere 60: 542-551. 
Crock J.G., Severson R.C., 1980. Geological Survey Circular 84: $1-16$.

Deboudt K., Flament P., Bertho B., 2004. Cd, $\mathrm{Cu}, \mathrm{Pb}$ and $\mathrm{Zn}$ concentrations in atmospheric wet deposition at a coastal station in Western Europe. Water Air Soil Pollution 151: 335-359.

Hursthouse A., Toguarelli D., Tucker P., Ajmone Marsal F., Martini L., Madrid L., 2004. Metal content of surface soils in park and allotments from three European cities, initial pilot study results. Land Contamination and Reclamation 12: 189-196.

Kalembkiewicz J., Sitarz-Palczak E., Soco E., Nowak D., Trojnar I., 2014. Mobile fractions in dustfall and possible migration of metals to soil. Soil Science Annual 65(3): 126-129.

Ladonin D.V., Karpukhin M.M., 2008. Effect of the main soil components on the sorption of copper, zinc and lead by urban soils. Moscow University Soil Science Bulletin 63(3): 130135.

Lee C.S., Li X.D., Shi W.Z., Cheung S.C., Thornton I., 2006. Metal contamination in urban, suburban and country park soils of Hong Kong study based on GIS and multivariate statistics. Science of Total Environment 356: 45-61.

Lerner D.N., 1996. Urban ground water - an asset for the sustainable city. Journal of European Water Pollution Control 6: 43-51.

Li X., Poon Ch., Lin P., 2001. Heavy metal contamination of urban soils and street dust in Hong-Kong. Applied Geochemistry 16(11/12): 1361-1368.

Madrid L., Diaz-Barrientos E., Reinoso R., Madrid F., 2004. Metals in urban soils of Sevilla: seasonal changes and relations with other soil components and plant contents. European Journal of Soil Science 55: 209-217.

Madrid L., Diaz-Barrientos E., Reinoso R., Biasioli M., Davidson C.M., 2006. Variability in concentrations of potentially toxic elemnts in urban parks from six European cities. Journal of Environmental Monitoring 8: 1158-1165.

Mielke H.W., Gonzales C.R., Powell E., Shah A., Mielke P.W., 2002. Natural and anthropogenic processes that concentrate $\mathrm{Mn}$ in rural and urban environments of the lower Mississippi river delta. Environmental Research Section A 90: 157-168.

Miller W.P., Martens D.C., Zelazny L.W., 1986. Effect of sequence in extraction of trace metals from soils. Soil Science Society of America Journal 50: 598-601.

Mohrlok U., Schiedek T., 2007. Urban impact on soil and groundwater from infiltration processes to integrated urban water management. Journal of Soils and Sediments 7: 68.

Oktaba L., Paziewski K., Kwasowski W., Kondras M., 2014. The effect of urbanization on soil properties and soil organic carbon accumulation in topsoil of Pruszków a medium-sized city in the Warsaw Metropolitan Area, Poland. Soil Science Annual 65(1): 10-17.

Polish Soil Classification (Systematyka Gleb Polski), 2011. Roczniki Gleboznawcze - Soil Science Annual 62(3): 1-193 (in Polish with English summary).

Poyat R.V., Yesilonis I.D., Russell-Anelli J., Neerchal N.K., 2007. Soil chemical and physical properties that differentiate urban land use and cover types. Soil Science Society of America Journal 71: 1010-1019.

Regulation of the Minister of the Environment dated September 9, 2002 on soil and land quality standards (Journal of Laws 165, item 1359, October 4, 2002).

Shi G.T., Chen S.Y., Xu J., Zhang L., Wang C.J. Bi J.Y., 2008. Potentially toxic metal contamination of urban soils and roadside dust in Shanghai, China. Environmental Pollution 156: $251-260$.

\section{Formy i mobilność pierwiastków śladowych w glebach terenów parkowych Bydgoszczy}

\footnotetext{
Streszczenie: Rosnąca aktywność ludzi wpływa na ekosystemy miejskie, w tym na gleby. Celem przeprowadzonych badań było: oznaczenie zawartości ołowiu, kadmu, miedzi, cynku i manganu w glebach parków miejskich i terenów zielonych aglomeracji bydgoskiej, określenie ich formy i mobilności, charakterystyka ich rozmieszczenia w profilu glebowym oraz próba określenia ich pochodzenia - antropogenicznego lub naturalnego. Do badań wybrano trzy obszary zielone położone w starej części Bydgoszczy. Do oznaczeń zastosowano wieloetapową, sekwencyjną ekstrakcję umożliwiającą oznaczenie siedmiu frakcji metali. Stwierdzono nieznaczne zanieczyszczenie badanych gleb metalami, w szczególności cynkiem i ołowiem. Metale te występują głównie w stosunkowo mało mobilnych formach, tj. związanych z amorficznymi i krystalicznymi tlenkami żelaza oraz materią organiczną w glebie. Rozmieszczenie profilowe badanych metali było zróżnicowane, będąc głównie wynikiem zachodzących procesów wymywania oraz wymieszania materiału glebowego i obecności domieszek.
}

Stowa kluczowe: gleby parków, pierwiastki śladowe, mobilność 